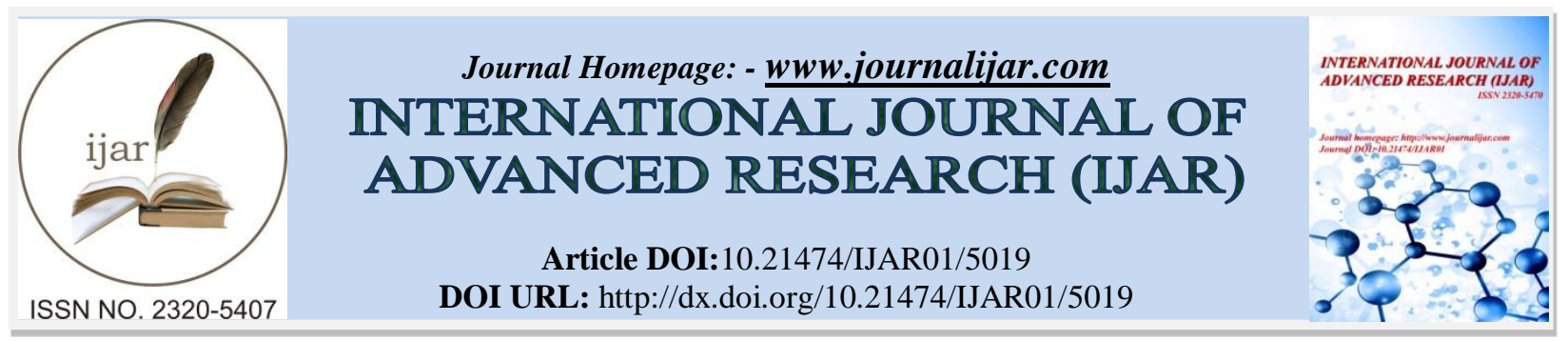

RESEARCH ARTICLE

\title{
ECO-FRIENDLY SYNTHESIS OF 2-PYRAZOLINE AND ITS Cr(III) - COMPLEXES AS POTENT ANTIMICROBIAL AGENT.
}

\author{
Rashmi Sharma ${ }^{1}$ and Dr. Ajay M. Chaturvedi ${ }^{2}$. \\ 1. Department of Chemistry, P.M.B. Gujarati Science College, Indore (M.P.). \\ 2. Department of Chemistry, Govt. Madhav Science P.G. College, Ujjain (M.P.).
}

\section{Manuscript Info}

.........................

Manuscript History

Received: 28 May 2017

Final Accepted: 30 June 2017

Published: July 2017

Key words:-

Pyrazolines, microwave, antimicrobial activity, thiosemicarbazide.

\section{Abstract}

Complexes of 1-Thiocarbamoyl-3,5-diphenyl-2-pyrazolines with $\mathrm{Cr}(\mathrm{III})$ have been synthesized using microwave induced methodology. A considerable increase in the reaction rate has been observed, with better yields. The synthesized compounds have been characterized on the basis of elemental analysis, molecular weight determination and spectral data like ${ }^{1} \mathrm{H}-\mathrm{NMR}$, IR and screened for their antimicrobial activities in vitro against common bacterial strains.

Copy Right, IJAR, 2017,. All rights reserved.

\section{Introduction:-}

Microwave assisted synthesis in organic chemistry is an important and well established area of research due to a number of advantages over conventional heating methods. ${ }^{1}$ The microwave assisted reaction occurs more rapidly safely and with higher chemical yields rendering this method superior to the conventional methods which requires longer reaction period, tedious work up, use of large quantity of solvents and reagents causing environmental pollution. In recent years the compounds with hetero atoms are very much used as antimicrobial agents. A number of thiosemicarbazide derivatives have been reported to possess insecticidal, bactericidal, and herbicidal activities. ${ }^{2-5}$ The pyrazoline derivatives due to their non toxic properties and a wide range of biological activities ${ }^{6-9}$ have been used extensively in medicinal chemistry. Interest of coordination chemistry increasing continuously with preparation of organic ligand containing oxygen and nitrogen donor ligands which have biological importance. ${ }^{10-11}$ The number of nitrogen and oxygen/sulfur chelating agent used to prepare new coordination compounds have increasing rapidly in current century. ${ }^{12-13}$ Nitrogen containing compounds and their metal complexes have antimicrobial activity. Due to the presence of multi-coordination center 2-pyrazolines have the ability to form stable chelates with essential metal ion. ${ }^{\text {14-15 }}$ Keeping in view of the advantages of microwave heating all the transformations in present investigation have been carried out using Microwave induced technique.

\section{Material and methods:-}

Domestic microwave oven of $2.54 \mathrm{GHz}$. modified for 'reflux organic synthesis' was used within 100-300 watt level, for MWI methods. Microwave safe 'borosil' glass apparatus were used for the synthesis in microwave oven. All the compounds were synthesized by using analytical grade chemicals of Across Organics, Fisher Scientific, CDH, and Merck. All the synthesized compounds were characterized by melting point determination, elemental analysis, FTIR, ${ }^{1} \mathrm{H}-\mathrm{NMR}$ and LCMS spectral studies. 


\section{Synthesis of substituted 2-Pyrazolines:-}

Substituted 2-Pyrazoline was synthesized by MWI method. The general method for the synthesis of substituted 2Pyrazoline is as follows:

Benzalacetophenone $(0.01 \mathrm{~mole})$ was treated with Thiosemicarbazide $(0.01 \mathrm{~mole})$, and their mixture solution was microwave irradiated for 10-15 minutes cautiously at low temperature in modified microwave oven ${ }^{16-18}$ and1Thiocarbamoyl-3,5-diphenyl-2-pyrazoline was synthesized. The analytical and physical data of the synthesized compound is summarized in Table $\mathbf{- 1}$.

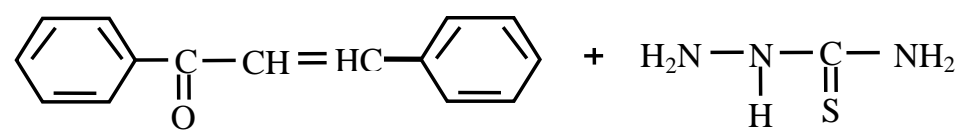

Benzalacetophenone

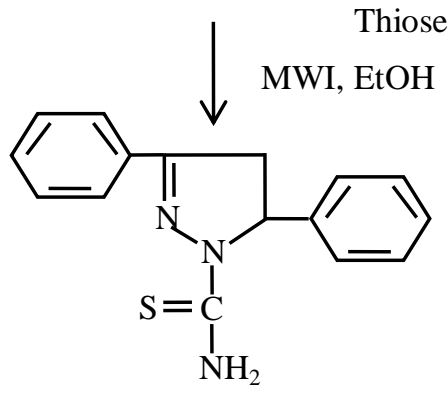

1-Thiocarbamoyl-3,5-diphenyl-2-

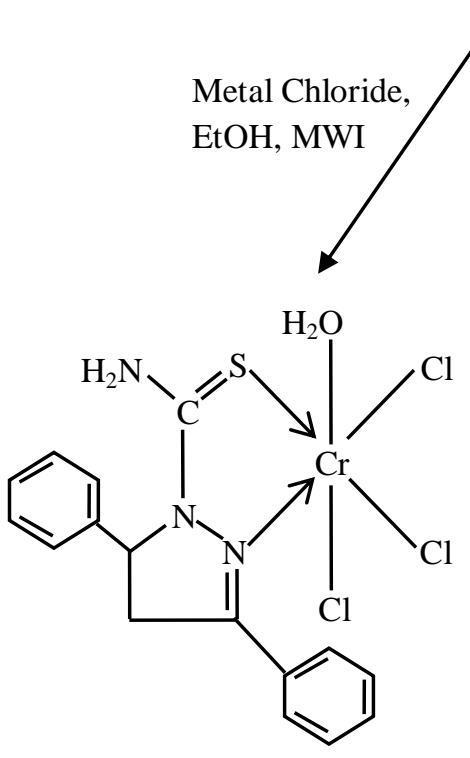

Bidentate mode in 1:1 ratio

pyrazoline

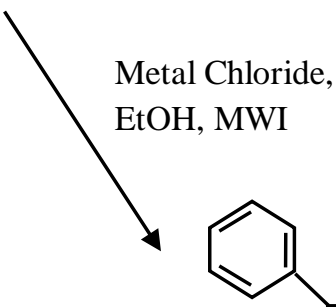<smiles>C=CCC1=NN(C(N)=[SH]CC(C)(Cl)N2N=C(c3ccccc3)CC2c2ccccc2)C(c2ccccc2)CC1c1ccccc1</smiles>

Bidentate mode in 1:2 ratio

Scheme :- 1

\section{Synthesis of metal complexes:-}

$\mathrm{Cr}$ (III) complexes of 1-Thiocarbamoyl-3,5-diphenyl-2-pyrazoline in 1:1 and 1:2 molar ratio were synthesized by MWI method. ${ }^{19-26}$

\section{MWI method for 1:1 ratio:-}

1-Thiocarbamoyl-3,5-diphenyl-2-pyrazoline $(2 \mathrm{mmol})$ and metal salt $(2 \mathrm{mmol})$ [for 1:2 molar ratio metal salt $(1 \mathrm{mmol})$ was taken] were dissolved separately in minimum quantity of hot absolute alcohol (10ml). 1-Thiocarbamoyl-3,5diphenyl-2-pyrazoline solution was added slowly to the metal salt solution with constant stirring in $150 \mathrm{ml}$ borosil round bottom flask and kept in modified domestic microwave oven, cooled by ice cold water. The reaction mixture was then subjected to microwave irradiation for 10-15 minutes, till the colour of reaction mixture underwent a change, and then it was cooled at room temperature. Greenish yellow coloured solid thus obtained was filtered and washed with ethanol and benzene thoroughly. It was dried at room temperature over anhydrous calcium chloride in a 
desiccator, then precipitated from ethanol, and dried in vacuo. The analytical and physical data of the synthesized compound is summarized in Table- 2.

Table1:-Analytical and Physical data of Synthesized Pyrazolines.

\begin{tabular}{|c|c|c|c|c|c|c|c|c|c|}
\hline \multirow[b]{2}{*}{ Product } & \multirow{2}{*}{$\begin{array}{l}\text { Molecular } \\
\text { formula }\end{array}$} & \multirow{2}{*}{$\begin{array}{c}\text { M.W. } \\
\begin{array}{c}\text { Found(calculated) } \\
\text { in } \mathbf{g} / \mathbf{m o l}\end{array}\end{array}$} & \multirow[b]{2}{*}{ Colour } & \multirow[b]{2}{*}{$\begin{array}{l}\text { M.P. } \\
\left({ }^{\circ} \mathbf{C}\right)\end{array}$} & \multirow[b]{2}{*}{$\begin{array}{l}\text { Yield } \\
(\%)\end{array}$} & \multicolumn{4}{|c|}{ Elemental analysis found (calculated) } \\
\hline & & & & & & $\% \mathrm{C}$ & $\% \mathrm{H}$ & $\% \mathrm{~N}$ & $\% \mathrm{~S}$ \\
\hline $2 \mathbf{a}$ & $\mathrm{C}_{16} \mathrm{H}_{15} \mathrm{SN}_{3}$ & $281.37(280.3)$ & $\begin{array}{c}\text { Pale } \\
\text { yellow }\end{array}$ & 165 & 55 & $\begin{array}{c}68.3 \\
(68.6)\end{array}$ & $\begin{array}{l}5.37 \\
(5.8)\end{array}$ & $\begin{array}{l}14.93 \\
(15.2)\end{array}$ & $\begin{array}{c}11.4 \\
(11.8)\end{array}$ \\
\hline
\end{tabular}

The analytical and comparative physical data of the some compounds are summarized as follows:

Table2:-Analytical and physical data for 1-Thiocarbamoyl-3,5-diphenyl-2-pyrazoline and its metal complex In 1:1 and $1: 2$ ratio.

\begin{tabular}{|c|c|c|c|c|c|c|c|c|c|c|}
\hline \multirow{2}{*}{$\begin{array}{c}\text { Cd. } \\
\text { No }\end{array}$} & Product & $\begin{array}{c}\text { M.W. } \\
\text { Found } \\
(\mathbf{c a l c}) \text { in } \\
\text { g/mol }\end{array}$ & $\begin{array}{c}\text { Yield } \\
(\%)\end{array}$ & $\begin{array}{c}\text { M.P. } \\
\left({ }^{\circ} \mathbf{C}\right)\end{array}$ & $\mathbf{\%} \mathbf{C}$ & $\mathbf{\%} \mathbf{H}$ & $\mathbf{\%} \mathbf{~ N}$ & $\mathbf{\%} \mathbf{S}$ & $\mathbf{\%} \mathbf{C l}$ & $\mathbf{\%} \mathbf{~ C r}$ \\
\hline $1 \mathrm{a}$ & $\left(\mathrm{C}_{16} \mathrm{H}_{15} \mathrm{SN}_{3} \cdot \mathrm{H}_{2} \mathrm{O}\right) \mathrm{CrCl}_{3}$ & $\begin{array}{c}456.4 \\
(457.74)\end{array}$ & 80 & 164 & $\begin{array}{c}41.62 \\
(41.98)\end{array}$ & $\begin{array}{c}3.21 \\
(3.74)\end{array}$ & $\begin{array}{c}9.02 \\
(9.18)\end{array}$ & $\begin{array}{c}7.10 \\
(7.00)\end{array}$ & $\begin{array}{c}23.12 \\
(23.24)\end{array}$ & $\begin{array}{c}11.03 \\
(11.36)\end{array}$ \\
\hline $1 \mathrm{~b}$ & $\left(\mathrm{C}_{16} \mathrm{H}_{15} \mathrm{SN}_{3}\right)_{2} \mathrm{CrCl}_{3}$ & $\begin{array}{c}720.46 \\
(721.10)\end{array}$ & 80 & 170 & $\begin{array}{c}53.0 \\
(53.3)\end{array}$ & $\begin{array}{c}4.11 \\
(4.19)\end{array}$ & $\begin{array}{c}11.02 \\
(11.65)\end{array}$ & $\begin{array}{c}8.13 \\
(8.89)\end{array}$ & $\begin{array}{c}14.39 \\
(14.75)\end{array}$ & $\begin{array}{c}7.10 \\
(7.21)\end{array}$ \\
\hline
\end{tabular}

Spectral data of compounds:-

(2a) 1-Thiocarbamoyl-3,5-diphenyl-2-pyrazoline:-

$\operatorname{IRv}\left(\mathrm{cm}^{-1}\right): 1582(\mathrm{C}=\mathrm{N}), 1071(\mathrm{C}-\mathrm{N}), 827(\mathrm{~N}-\mathrm{N}), 1564 \& 3000-3042(\mathrm{Ar}-\mathrm{Nu}), 1147(\mathrm{C}=\mathrm{S}) ;{ }^{1} \mathrm{H}-\mathrm{NMR} \delta(\mathrm{ppm}): 3.3-$ 3.1 $\left(\mathrm{C}_{4}-\mathrm{CH}_{2}\right), 4.0\left(\mathrm{C}_{5}-\mathrm{CH}\right), 7.7-6.6(\mathrm{Ar}-\mathrm{H})$.

(1a) $\mathrm{Cr}$ (III) chelate in 1:1 ratio:-

$\operatorname{IRv}\left(\mathrm{cm}^{-1}\right): 1109(\mathrm{C}=\mathrm{S}), 1539(\mathrm{C}=\mathrm{N}), 3268 \& 1632\left(\mathrm{H}_{2} \mathrm{O}\right), 478(\mathrm{Cr}-\mathrm{N}), 512(\mathrm{Cr}-\mathrm{S}) ;{ }^{1} \mathrm{H}-\mathrm{NMR} \delta(\mathrm{ppm}): 3.3-3.1\left(\mathrm{C}_{4}-\mathrm{CH}_{2}\right)$, 4.0 $\left(\mathrm{C}_{5}-\mathrm{CH}\right), 7.7-6.6(\mathrm{Ar}-\mathrm{H})$

(1b) $\mathrm{Cr}$ (III) chelate in 1:2 ratio:-

$\operatorname{IRv}\left(\mathrm{cm}^{-1}\right): 1144(\mathrm{C}=\mathrm{S}), 1566(\mathrm{C}=\mathrm{N}), 478(\mathrm{Cr}-\mathrm{N}), 512(\mathrm{Cr}-\mathrm{S}) ;{ }^{1} \mathrm{H}-\mathrm{NMR} \delta(\mathrm{ppm}): 3.3-3.1\left(\mathrm{C}_{4}-\mathrm{CH}_{2}\right), 4.0\left(\mathrm{C}_{5}-\mathrm{CH}\right), 7.7-6.6$ $(\mathrm{Ar}-\mathrm{H})$

\section{Antimicrobial activity:-}

The biocidal activity of synthesized substituted pyrazoline and its metal complexes was studied in order to prove their utility. For this purpose, some bacteria's like Staphylococcus aureus (gram positive bacteria), Pseudomonas spp. (gram positive bacteria), Escherichia coli (gram negative bacteria), Bacillus cereus (gram negative bacteria) were cultured on Mueller- Hinton agar plates and by using block well diffusion method, then the effect of synthesized pyrazoline and its $\mathrm{Cr}$ (III) metal complexes were screened. All the synthesized compounds exhibited moderate to excellent antibacterial activities. Some of them were found to be more effective in comparison to standard drugs (Amikacin and Gentamicin). Antimicrobial activity of the synthesized compounds is represented in table 3.

Table3:-Antimicrobial activity of $\mathrm{Cr}(\mathrm{III})$ complex of 1-thiocarbamoyl-3,5-diphenyl-2-pyrazoline in 1:1 and 1:2 ratio

\begin{tabular}{|c|c|c|c|c|c|c|c|c|}
\hline \multirow{2}{*}{$\begin{array}{c}\text { Compound } \\
\text { (metal } \\
\text { complex) }\end{array}$} & \multicolumn{9}{|c|}{ Zone of inhibition in mm } \\
\cline { 2 - 9 } & \multicolumn{9}{|c|}{ S. Aureus } & \multicolumn{2}{c|}{ E. Coli } & \multicolumn{2}{c|}{ Pseudomonas } & \multicolumn{2}{c|}{ Bacillus } \\
\cline { 2 - 9 } & Zone size & Activity & Zone size & Activity & Zone size & Activity & Zone size & Activity \\
\hline 1a & 12 & I & 10 & I & 12 & I & 20 & E \\
\hline 1b & 10 & I & 10 & I & 20 & E & 18 & S \\
\hline Std. Drug & 05 & R & 12 & I & 12 & I & 16 & S \\
(Amk and Gen) & 06 & R & 12 & I & 14 & I & 18 & S \\
\hline
\end{tabular}

Where, $\mathrm{R}_{1}=$ Amikacin $\quad \mathrm{R}_{2}=$ Gentamicin $\mathrm{I}=$ Intermediate (weak activity) $\mathrm{S}=$ Susceptible (good activity) $\quad \mathrm{E}=$ Excellent activity 


\section{Results and Discussion:-}

In this paper, microwave assisted synthesis of 2-Pyrazoline (2a) and its metal complexes (1a and 1b) have been reported by the reaction of substituted chalcones with thiosemicarbazide under microwave irradiation to yield 2Pyrazolines (2a), in 10-15 minutes. These pyrazoline were treated with metal chloride under microwave irradiation to yield $\mathrm{Cr}(\mathrm{III})$ chelates. The synthetic procedure for preparation of titled compounds is given in reaction scheme I. The assigned structure and molecular formula of the newly synthesized compounds (2a, 1aand $\mathbf{2 b}$ ) were confirmed and supported by ${ }^{1} \mathrm{H}$ - NMR and IR data as well as elemental analysis, which was in full agreement with proposed structures. All the compounds were screened in vitro for their antibacterial potential by block well diffusion assay against selected bacteria. The results of antibacterial activities expressed in terms of zone of inhibition are reported in Table 3. All the synthesized compounds have shown significant to excellent activity against E. coli, S. aureus, Bacillus and Pseudomonas.

\section{Conclusion:-}

In summary, this work demonstrates a rapid, efficient and environment friendly method for the synthesis of these compounds (substituted chalcones and 2-pyrazolines) under microwave irradiation. The results obtained confirm that the use of microwave has shown the advantages like high yields, relatively short reaction times, low cost, simple experimental and isolation procedures, and finally, it is in agreement with the green chemistry protocols. The results of antimicrobial studies of synthesized compounds revealed that they possess moderate to potent antibacterial activities against the tested gram positive and gram negative microorganisms. The data reported in this paper may be helpful as a guide for the medicinal chemists, who are working in this area.

\section{References:-}

1. S.V. Kasi and T.K.Raja.,(2006),Indianj.Heterocyclic Chem..,16, 195

2. J. R. Krazer And B.Sidney.,Ger.Offen., (1970), Chem. Abstr., 72, 32-43.

3. Ciba Ltd., Fr. Pat., (1969), Chem. Abstr.,71, 91052,

4. L. Stadnyk., R.S. Campbell and B.T.Johnson., (1971), Bull. Environ. Contaim. Toxicol.,6, 108,

5. H.D. Sally., (1947),J.Pharmacol. 90,260,

6. J.C. Maruzella and P.A.Henery., (1958), J.Am.Pharm.Assoc., 47,298,

7. J.G. Vincent., and H.W. Vincent.,(1955), Proc.Expt. Biol. Med. 55, 162,

8. T.C. Sharma., M. M. Bokadia and N.J.Reddy., (1980), Indian J.Chem.19b,228

9. G.D. Thorn., (1961), Phytopathology., 51,77

10. Kulkarni, P.G. Avaji, G.B. Bagihalli. S.A.Patil And P.S. Badami, (2009), Journal Of Coordination Chemistry Vol 62, No. 3 481-492

11. K.Sharma, R.V. Singh and N. Farmi, (2001),Spectrochemi acta Part A, Vol.78 No.1 80-87,

12. T.S. Basu, Baul, (2008), Applied Organomatallic Chemistry Vol. 22, 195-204.

13. J. Zhou, H Zhao, C-L Chen, and J.P. Wang, (2009), Journal Of Coordination Chemistry Vol. 62, No.9, 14231429.

14. D. Shanker, R.K. Sharma, J. Sharma, A.K. Rai, And Y.P. Singh, (2007), Hetero Atom Chemistry Vol. 18 No.1,70- 75 .

15. K. Singh, P.P. Singh M. Singh, Barwa, P. Tyagiand, Y. Mirza,(2006), Journal Of Enzyme Inhibition And Medicinal Chemistry, Vol, 21, No.6,749-755.

16. Vikas Tiwari et.al.(2011), Microwave Assisted Improved Synthesis Of Chalcones Under Microwave Irradiation And Their Antibacterial Activity, J. Chem. Bio. Phy. Sci., Vol.1, 22-27.

17. R. Revathi et.al.(2013), Microwave Assisted Synthesis And Biological Activity Of Certain 4-Hydroxy Chalcones, Pharmacophore, Vol.4(2), 59-69.

18. Dav Oodazafifar et.al.(2003), Microwave Assisted Synthesis Of Some 3,5-Arylated 2-Pyrazoline, Molecules, Vol. 8, 642-648.

19. N.S. Rao et.al.(2009), Microwave Induced Synthesis And Antimicrobial Activities Of Some $\mathrm{N}^{1}$ - Morpholino Ethanoyl-3,5- Diaryl-2-Pyrazoline Derivatives, Rasayan J. Chem., Vol. 2(3), 716-719.

20. Pankaj Malhotra et.al.(2010), Microwave Assisted Synthesis And Anti- Inflamatory Activity Of 3,5-Diaryl Subsituted-2-Pyrazolines, International Journal Of Pharmacy And Pharmaceutical Sciences, Vol.2(2), 21-26.

21. Bharat Parashar et.al.(2010), Comparative Conventional And Microwave Assisted Synthesis Of Some Pyrazoline Derivatives and Their Antimicrobial Activity, Journal Of Chemical And Pharmaceutical Research, Vol.2(3), 33-42. 
22. Rakesh Chawla et.al.(2010), Microwave Assisted Synthesis Of Some Novel 2-Pyrazoline Derivatives As Possible Antimicrobial Agents, Acta poloniaepharmaceutica-Drug Research, Vol. 67(1),55-61.

23. Biresh K. Sarkar et.al.(2011),Antimicrobial Activity Of Some Novel Pyrazoline Derivatives, Journal Of Advanced Pharmacy Education And Research, Vol. 1(5), 243-250.

24. S. Shah N.N. et.al.(2011), Synthesis And Antimicrobial Studies Of Some Novel Pyrazolines Derived From Piperazine chalcones, International Journal Of Current Pharmaceutical Research, Vol.3(2), 34-36.

25. Shahanaehsan et.al.(2012), Microwave Assisted Synthesis Of Nitrogen And Hydroxyl Containing Bioactive Compounds As Drug Motif, International Journal Of Science And Research, Vol.3(9), 195-199.

26. Ganguly SS et.al.(2012), Synthesis And Antimicrobial Activities Of Some Pyrazoline Derivatives, International Journal For Pharmaceutical Research Scholars, Vol 1(4), 33-39. 